\title{
SISTEM EKONOMI KAPITALISME
}

\section{Fitrah Rahma Inayah (90100118034)}

Permasalahan ekonomi yang sering muncul di masyarakat menyangkut tiga masalah pokok yaitu barang ataupun jasa apa yang akan diproduksi. Dalam mengatasi masalah tersebut diperlukannya cara tertentu untuk menjalankan perekonomian negara, cara tersebut dinamakan sistem ekonomi. Sistem ekonomi adalah suatu cara untuk mengatur dan mengorganisasi segala aktivitas perekonomian masyarakat baik yang dilakukan pemerintah atau swasta berdasarkan prinsip tertentu dalam rangka mencapai kemakmuran atau kesejahteraan (Effendi, 2019).

\section{Pengertian Sistem Ekonomi Kapitalisme}

Sistem ekonomi adalah sekumpulan komponen-komponen atau unsur-unsur yang terdiri dari atas unit-unit dan agen-agen ekonomi, serta lembaga-lembaga ekonomi yang bukan saja saling berhubungan dan berinteraksi melainkan juga sampai tingkat tertentu yang saling menopang dan memengaruhi (Itang and Daenuri 2017). Sedangkan kapitalisme merupakan sebuah sistem organisasi ekonomi yang dicirikan oleh hak milik privat atas alat-alat produksi dan distribusi yang pemanfaatannya untuk mencapai laba dalam kondisi yang sangat kompetitif (Agustiati, 2009).

Sistem kapitalis memandang bahwa manusia merupakan pemilik satusatunya terhadap harta yang telah diusahakannya dan tidak hak atas orang lain di dalamnya. Ia memiliki hak mutlak untuk membelanjakan sesuai dengan keinginannya. Sosok pribadi dipandang memiliki hak untuk memonopoli saranasarana produksi sesuai kekuasaannya. Ia mengalokasikan hartanya hanya pada bidang yang memiliki nilai guna materi (profit oriented) (Effendi, 2019).

\section{Ciri-Ciri Sistem Ekonomi Kapitalisme}

Setiap sistem ekonomi pasti memiliki ciri khas tersendiri dalam pelaksanaannya. Adapun ciri dari sistem ekonomi kapitalis yaitu (Azhar, 2017):

1. Kebebasan memiliki harta secara perorangan. Dalam paham kapitalisme tidak berlaku istilah hak milik berfungsi sosial, karena pemberian hak milik secara 
mutlak akan menciptakan perilaku inidividu untuk menggunakan semaksimal mungkin sumber daya yang dimiliki.

2. Kebebasan ekonomi dan persaingan bebas. Individu berhak terjun dalam bidang perniagaan dan memperoleh keuntungan sebanyak-sebanyaknya dan negarapun tidak boleh campur tangan di dalamnya.

3. Mementingkan diri sendiri. Aktivitas individu diyakini tidak akan membawa kekacauan, bahkan sebaliknya akan membawa kemakmuran bangsa-bangsa seperti yang dikatakan oleh Adam Smith.

4. Perekonomian diatur oleh mekanisme pasar. Setiap harga barang yang ada di pasar sudah ditentukan oleh permintaan dan penawaran yang dilakukan secara bebas.

5. Manusia dipandang sebagai makhluk homo-economicus, yang selalu mengejar kepentingan ataupun keuntungan sendiri.

6. Campur tangan pemerintah minimum. Dalam sistem ekonomi kapitalis, yang sangat berperan adalah individu bukan pemerintah, karena pemerintah memberikan kebebasan kepada para pemodal untuk mengembangkan usahanya.

\section{Konsep Ekonomi Kapitalisme}

Konsep ekonomi kapitalis adalah suatu sistem yang memberikan kebebasan yang seluas-luasnya kepada individu untuk melakukan perekonomian. Konsep ini adalah hasil dari pemikiran Adam Smith seorang tokoh mazhab klasik dimana para ahli ekonomi dunia menilai bahwa pemikiran mazhab klasik merupakan dasar dari sistem ekonomi kapitalis. Adam smith dalam teorinya menghendaki setiap orang diberi kebebasan untuk berusaha dalam persaingan yang sempurna (Zainol Hasan and Mahyudi, 2020).

Kapitalisme menganggap kebebasan individu tanpa batas untuk mencari kekayaan pribadi adalah sebuah keharusan bagi individu. Ideologi ini membuka kebebasan kepada umat manusia seluas-luasnya tanpa ada batasan baik batasan keagamaan, sistem, tradisi maupun nilai dan norma (Tamsir, 2019). Kapitalisme sangat menjunjung tinggi hak-hak kepemilikan individu terhadap sumber daya ekonomi (Pangiuk, 1997). 


\section{DAFTAR PUSTKA}

Agustiati, A. (2009). Sistem Ekonomi Kapitalisme. Academica, 1(2).

Azhar, A. (2017). ANTARA EKONOMI ISLAM DAN EKONOMI KONVENSIONAL. Islamika: Jurnal Ilmu-Ilmu Keislaman, 17(2), 1-16.

Effendi, S. (2019). Perbandingan Sistem Ekonomi Islam Dengan Sistem Ekonomi Kapitalis dan Sosialis. JRAM (Jurnal Riset Akuntansi Multiparadigma), 6(2), 147-158.

Hasan, Z., \& Mahyudi, M. (2020). Analisis terhadap Pemikiran Ekonomi Kapitalisme Adam Smith. Istidlal: Jurnal Ekonomi dan Hukum Islam,4(1), 24-34.

Pangiuk, A. (1997). Kepemilikan Ekonomi Kapitalis Dan Sosialis (Konsep Tauhid Dalam Sistem Islam). Nalar Figh, 4(2).

Sirajuddin, S., \& Tamsir, T. (2019). REKONSTRUKSI KONSEPTUAL KEPEMILIKAN HARTA PERSPEKTIF EKONOMI ISLAM (Studi Kritis Kepemilikan Harta Sistem Ekonomi Kapitalisme). Laa Maisyir: Jurnal Ekonomi Islam, 6(2), 211-225. 